\title{
CFD STUDY THE IMPACT OF KEY PARAMETERS ON THE DISTRIBUTION OF SMOKE AND HAZARDS IN THE PREMISES
}

\author{
A. Terziev, I. Antonov ${ }^{(1)}$, Nguyen Thanh Nam ${ }^{(2)}$, Hoang Duc Lien ${ }^{(3)}$ \\ (1)Technical University-Sofia \\ (2)DCSELAB, University of Technology (HCMUT) \\ (3)Ha Noi University of Agriculture \\ (Manuscript Received on April $5^{\text {th }}, 2012$, Manuscript Revised November 20 ${ }^{\text {rd }}, 2012$ )
}

ABSTRACT: In modern buildings more diverse and new polymeric combustible materials widely used as coverings, beddings, thermal and acoustic insulation, equipment and furniture are applied. Some of these elements are able to release large amounts of smoke and heat in a very short period of time. The building can get extremely dangerous situations in presence of fire. Since the major task of fire protection technique is protecting people from injury, some answers to the following questions are seeks: how smoke will be spread into the room, is there a chance to be taken away without burning spread, which are the general parameters defining distribution of smoke and hazards in the premises and etc.

The solution of the problems raised above resorting to mathematical modeling of fires. For this purpose a numerical simulation of such processes are accomplished. Here are presented the results of spreading of smoke and hazards in a room occupied by people as particular attention is paid to a velocity and temperature field distribution. Based on the results of the numerical simulation, a scientific-based prognosis of the hazardous factors was made in order to optimize the work of the fire protection systems (smoke extraction systems, mechanical ventilation) by considering the physical characteristics of the room.

Key words: fire protection, smoke and hazard distribution, numerical modeling.

\section{INTRODUCTION}

When burning a number of materials significant parts of the composition of contemporary works, such as polymeric materials, covering elements, heat and sound insulation, equipment and furniture, are released in a short time large quantity of smoke and heat. In the most of the cases the values of the last two parameters are quite above the permissible values for a room according the standards as they create a real danger for residents.

The main task of fire protection technique is to protect people from the fire. In this regard, addressing the following key questions: How will spread smoke in a room, is there a possibility limiting the spread of flame, how to protect emergency escape routes and which solution is more reliable, etc. 
In modern science to achieve flexible, objective-oriented of fire protection normalization can be achieved by so-called mathematical modeling of fires, which is a decisive point in solving various problems of fire safety.

Complexity of the developing such a model, respectively mathematical method for the solution is based on many factors and nonlinear solutions of the tasks. The actual modeling of the combustion process is an extremely complex task, involving not only physical but also chemical kinetics. The burning itself as an uncontrollable, complex, portable, three-dimensional and thermophysical process accompanied by modification of chemical composition and parameters of the ambient gas in the room, which at present is not fully studied. In addition the mathematical model of the task is "aggravated" by the presence of turbulent convection and heat radiation, arising from the heat exchange between the gases and surrounding structures of the room.

The main purpose of this work is to implement numerical modeling and simulation of the spread of smoke and hazards in the specific living areas in compliance with the above stated conditions. The distribution of some important parameters (velocity and temperature) is accomplished. Scientifically substantiated forecast of the dynamics of the fire danger factors to optimize the activities of fire protecting and mechanical ventilation systems is done.

\section{MATHEMATICAL MODELING. NUMERICAL SIMULATION}

\subsection{Mathematical modeling}

Fire occurs in areas under complex thermoand gas dynamic conditions with simultaneous impact of several factors: non-thermal conditions, pressure gradients, purification, radiation, chemical interactions two-phase effects, turbulence, etc. The direct effect of the above factors leads to significant differences in the modeling of heat and mass exchange. The model describing these two simultaneously occurring process includes law conservation of mass, momentum and energy [3].

Below are presented in a general form of the above mentioned equations used in the numerical solution of the problem.

Mass conservation can be expressed with the following equation:

$\frac{\partial \rho}{\partial t}+\frac{\partial}{\partial x}(\rho u)+\frac{\partial}{\partial y}(\rho v)+\frac{\partial}{\partial z}(\rho w)=0,(1)$

where: $\rho$-density, $\mathrm{kg} / \mathrm{m}^{3}$;

$u, v, w$ - velocity components, $m / s$;

$x, y, z$ - Cartesian coordinates, $m$;

$t$ - time, $s$.

Energy conservation equation is presented as below:

$$
\rho c_{p}\left(\frac{\partial T}{\partial t}+u \frac{\partial T}{\partial x}+v \frac{\partial T}{\partial y}+w \frac{\partial T}{\partial z}\right)=
$$


$=\frac{\partial}{\partial x}\left[\lambda_{T} \frac{\partial T}{\partial x}\right]+\frac{\partial}{\partial y}\left[\lambda_{T} \frac{\partial T}{\partial y}\right]+\frac{\partial}{\partial z}\left[\lambda_{T} \frac{\partial T}{\partial z}\right]+q_{v}$

where: $T$ - temperature, $K$,

$q_{v}{ }^{-}$intensity of internal heat sources, $W / m^{3}$

The general coefficient of heat conductivity can be expressed with: $\lambda_{T}=\lambda+\lambda_{t}+\lambda_{r}$

where: $\lambda$ - heat conductivity coefficient, $W / m K$;

$\lambda_{t}$ - turbulent heat conductivity coefficient, $W / m K$;

$\lambda_{r}$ - radioactive heat conductivity coefficient, $W / m K$.

Turbulence model is based on the well known $k-\varepsilon$ model [1]. In this model it is assumed that the coefficient of turbulent viscosity depends on the turbulent kinetic energy, dissipation rate and according to Kolmogorov's equation [2] has the expression:

$$
v_{t}=C_{\mu} \frac{k^{2}}{\varepsilon}
$$

where: $v_{t} \quad-\quad$ kinematic turbulent coefficient, $m^{2} / s$;

$$
k=1 / 2\left(\bar{u}^{2}+\bar{v}^{2}+{\overline{w^{\prime}}}^{2}\right) \quad-\quad \text { turbulent }
$$

kinetic energy, $m^{2} / s^{2}$; $u^{\prime}, v^{\prime}, w^{\prime}$ - velocity fluctuations, $m / s ;$

$C_{\mu}=0.09$ - empirical constant.

Dissipation rate term is presented below:

$$
\varepsilon=v \overline{\left[\left(\frac{\partial u^{\prime}}{\partial x}\right)^{2}+\left(\frac{\partial v^{\prime}}{\partial y}\right)^{2}+\left(\frac{\partial w^{\prime}}{\partial z}\right)^{2}\right]}
$$

$m^{2} / s^{3}(4)$

In differential form the turbulent kinetic energy and dissipation rate are as follow:

$\rho \frac{d k}{d t}=\frac{\partial}{\partial x}\left(\frac{\mu_{t}}{\sigma_{k}} \frac{\partial k}{\partial x}\right)+\frac{\partial}{\partial y}\left(\frac{\mu_{t}}{\sigma_{k}} \frac{\partial k}{\partial y}\right)+\frac{\partial}{\partial z}\left(\frac{\mu_{t}}{\sigma_{k}} \frac{\partial k}{\partial z}\right)+$

$+v_{t}\left[\frac{\partial u_{j}}{\partial x_{i}}\left(\frac{\partial u_{i}}{\partial x_{j}}+\frac{\partial u_{j}}{\partial x_{i}}\right)+\frac{g}{\operatorname{Pr}_{t}} \frac{1}{T} \frac{\partial T}{\partial z}\right]-\varepsilon$

$\rho \frac{d \varepsilon}{d t}=\frac{\partial}{\partial x}\left(\frac{\mu_{t}}{\sigma_{\varepsilon}} \frac{\partial \varepsilon}{\partial x}\right)+\frac{\partial}{\partial y}\left(\frac{\mu_{t}}{\sigma_{\varepsilon}} \frac{\partial \varepsilon}{\partial y}\right)+\frac{\partial}{\partial z}\left(\frac{\mu_{t}}{\sigma_{\varepsilon}} \frac{\partial \varepsilon}{\partial z}\right)+$

$+C_{1} \frac{\varepsilon}{k} v_{t}\left[\frac{\partial u_{j}}{\partial x_{i}}\left(\frac{\partial u_{i}}{\partial x_{j}}+\frac{\partial u_{j}}{\partial x_{i}}\right)+\frac{g}{\operatorname{Pr}_{t}} \frac{1}{T} \frac{\partial T}{\partial z}\right]-C_{2} \frac{\varepsilon^{2}}{k}$ (6)

Where: $\operatorname{Pr}_{t}-$ Turbulent coefficient of Prandtl; $\mathrm{C}_{1}, \mathrm{C}_{2}, \sigma_{\mathrm{k}}, \sigma_{\varepsilon}, \sigma_{\mu}$ : the empirical constants in modeling equation has the values [1]: $C_{1}=1.44 ; \quad C_{2}=1.92 ; \sigma_{k}=1.0 ; \sigma_{\varepsilon}=1.3$; $\sigma_{\mu}=0.09$.

\subsection{Numerical simulation}

The numerical simulation is realized using a commercial CFD product [4]. The first step in the solution of the problem is geometric interpretation (geometric model) of the room. Here is presented a typical and a simple geometry of space, consisting of four walls, ceiling, floor, doors, windows and the source of heat, respectively hazards. 
The main purpose of simulation is to show the organization of the room air changes after fires, indicating areas with critical parameters of the emission of smoke and fire. This of course is possible only when a distribution of velocity and temperature field in the room is known

The presented room is $12 \times 12 \times 3.5$ meters. The building is a public service in education and has a class of functional fire hazard "F4" and the room is kind of classroom. Envelope of the room is as follows:

- West oriented wall - two of the iron window frames with dimensions $5.30 \times 2.50 \mathrm{~m}$, separated by a concrete column with dimensions $0.7 \times 0.7 \times 3.5$ meters. Wall was erected on one meter of elevation zero and consists of a brick wall with the plaster;

- South oriented wall - three windows of the same type with dimensions $3.30 \times 2.50$ meters, separated by concrete columns;

- East oriented wall - a brick wall with the plaster;

- North oriented wall - internal brick wall with lime mortar. In the middle of the wall is a door with an iron frame and windows with dimensions $2.70 \times 2.35$ meters.

The main smoke and hazard source is teacher department made by wood. The products of burning of teacher desk (smoke and hazards) with high temperature are subject to current numerical analysis. As a major factor seems to be smoke and it contains toxic substances.
In Fig. 1 shows the geometrical model of the hall, which will be carried out numerical simulations. The figure clearly shows the location of windows, doors, columns and generator of smoke and hazards - teacher desk.

The next step in the realization of the task is so cross-linking of the geometric model. The presence of the grid cell in the geometric volume is a prerequisite for carrying out the computational procedure.

The site is the cause of the fire department teacher of wood. Combustion smoke and high temperature hazards are subject to numerical analysis. As a major factor seems to be smoke and it contains toxic substances.

In Fig. 1 shows the geometrical model of the hall, which will be carried out numerical simulations. The figure clearly shows the location of windows, doors, columns and generator smoke and harmful - Department of teaching.

The next step in solving the problem is meshing the geometric model. The presence of the grid cell in the geometric volume is a prerequisite for carrying out the correct and complete computational procedure.

A large number of computational cells provide more detailed information about the distribution of the parameters. On the other hand, a large number of cells significantly increased computational time. It is important to find an optimal ratio between the number of cells and the desired accuracy. 
In this case, for meshing of the windows is selected step $0.2 \mathrm{~cm}$, while the rest of the room elements - 0.15 meters. For meshing is chosen the triangular cell. (Fig. 2a and b).

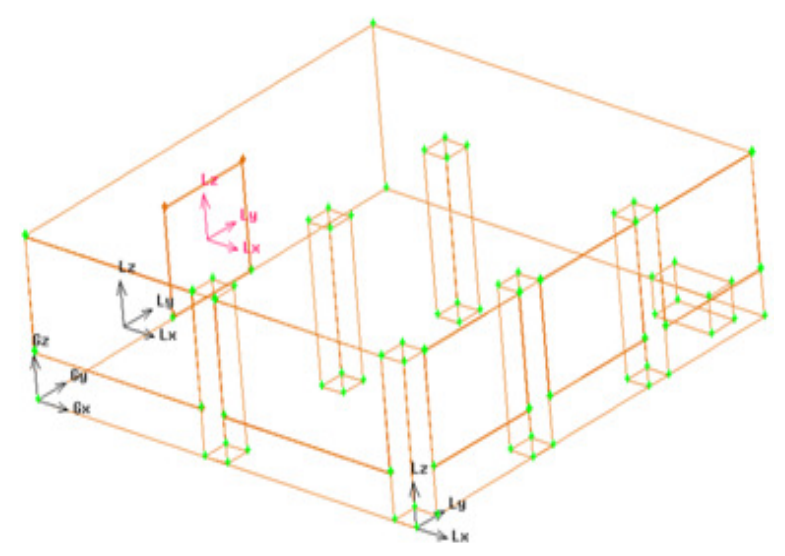

Figure 1. Geometric model of the investigated room

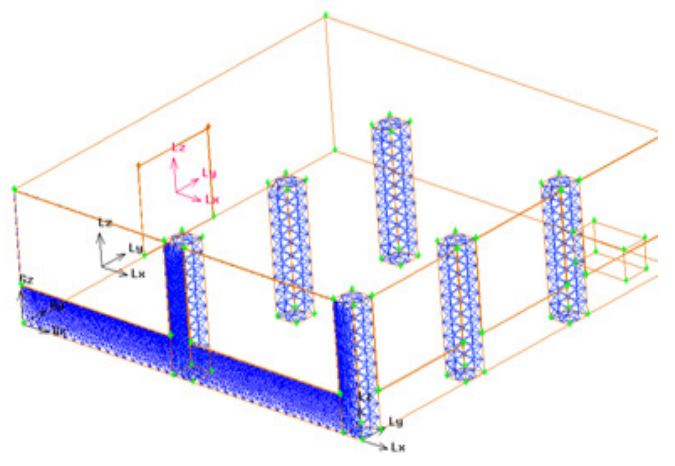

(a)

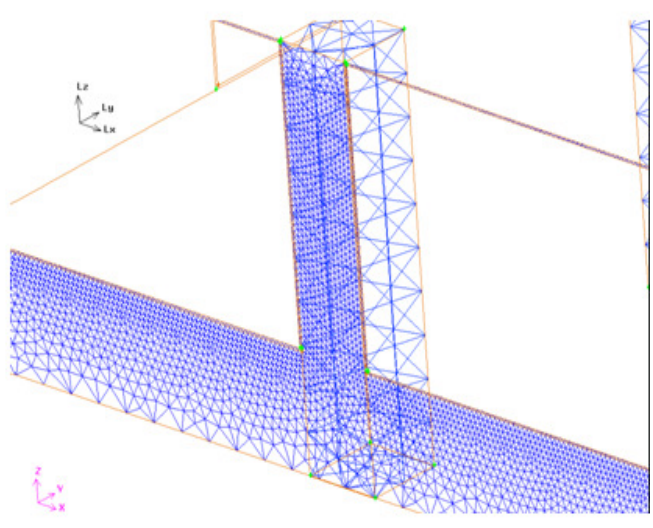

(b)

Figure 2. Meshing procedure of the geometric model

According to meshing criteria, the number of cells filling the geometric volume is about 700,000 . In setting the boundary conditions is assumed that the only source of smoke and hazards is the burning teaching desk. According to reference data for the smoke, the temperature is $T_{s}=550 \mathrm{~K}$. The convective velocity of the smoke is calculated automatically according to the preset room temperature. Smoke leaves the premise through the joints of windows and doors.

\section{RESULT FROM NUMERICAL SOLUTION}

During numerical solution is accepted the $k-\mathcal{E}$ model of turbulence. Heat transfer 
problem is solved with the introduction of the energy equation. After approximately 360 iterations according to preset criteria solution has been reached.

On the figures below are presented some significant parameter distribution from numerical simulation.

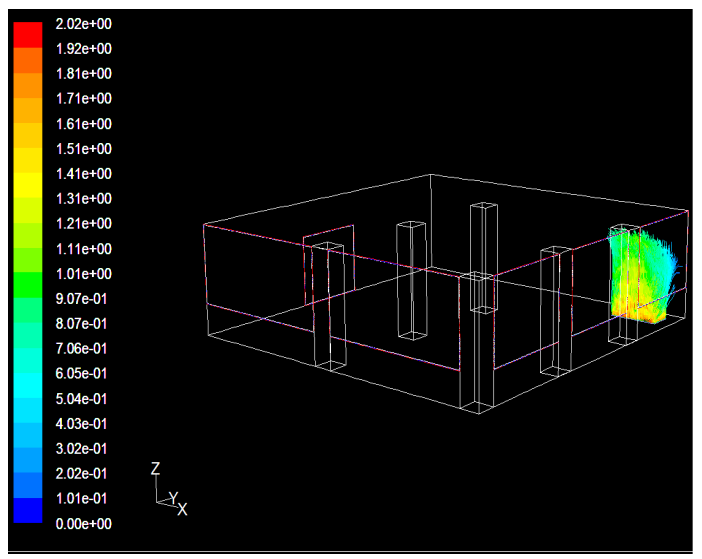

(a)

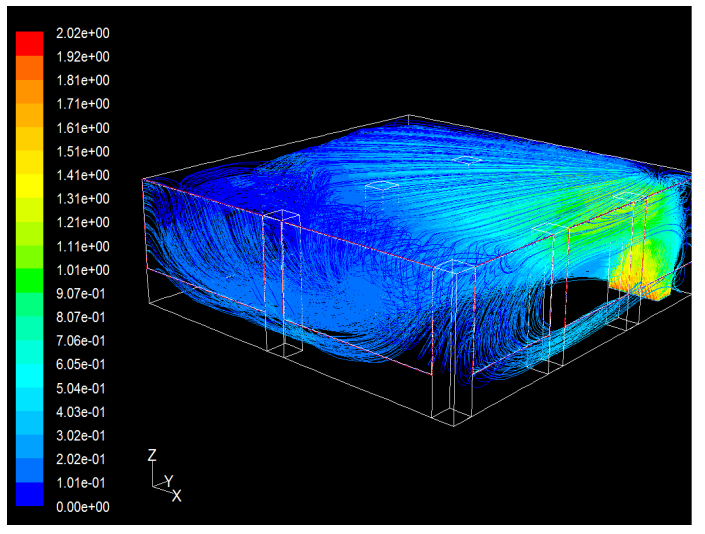

(c)
On Fig. $3 \mathrm{a}-\mathrm{d}$ is presented the velocity field distribution ( $m / s$ ) of smoke for different periods of time. From the figures, it is apparent that at the initial moment of time the smoke rises up perpendicular (Fig. 3a), then close to the ceiling reaches the opposite end of the room (Fig. 3b and c), then start to occupy the entire volume to the door.

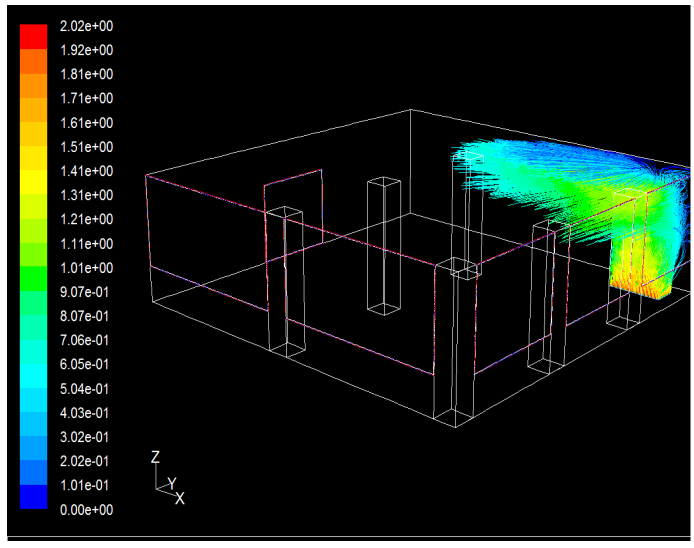

(b)

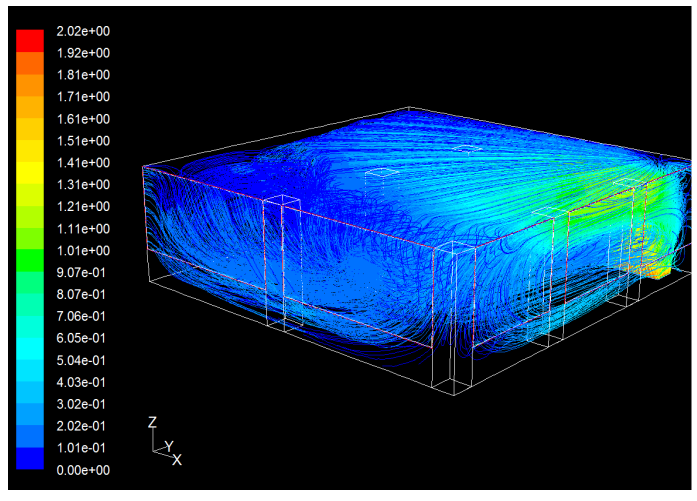

(d)

Figure 3. Velocity field distribution at different time

Temperature distribution through a vector image for different sections of the room is shown in Fig. 4a and b. It is obvious that the areas with the highest temperatures are near the burning site. The coldest part of the room is near the north wall of the room - opposite side of the burning object. 


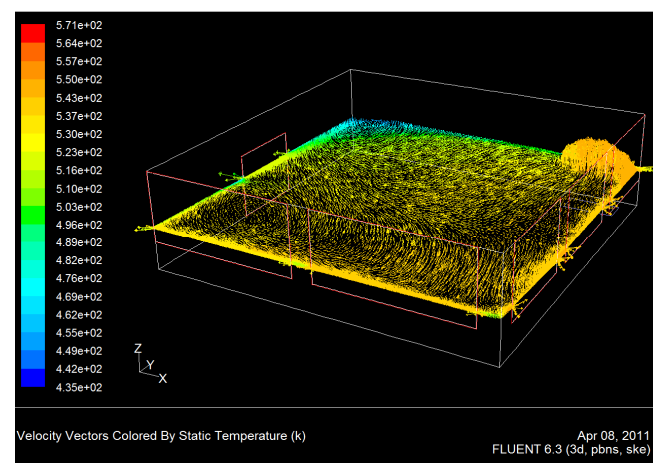

(a)

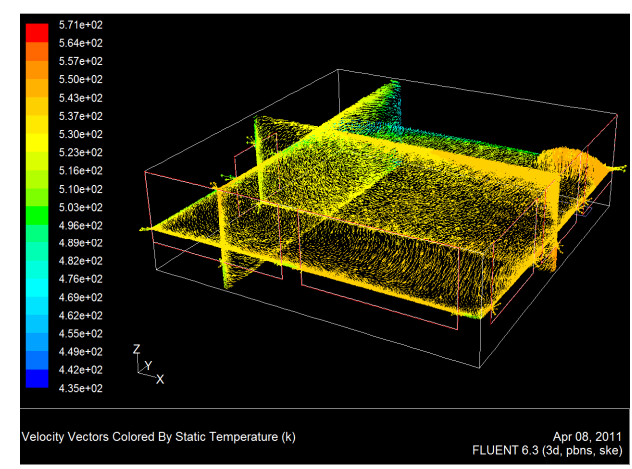

(b)

Figure 4. Temperature distribution for representative section of the room

The temperature distribution is due to the fact that smoke enters this section of the room after having "traveled" throughout the volume. Higher temperature is observed in the flow passing through the joints of windows and doors due to additional friction of the smoke through a thin slit.

In Fig. 5 shows the distribution of temperature field in the room with a fully developed fire (overall distribution of smoke in

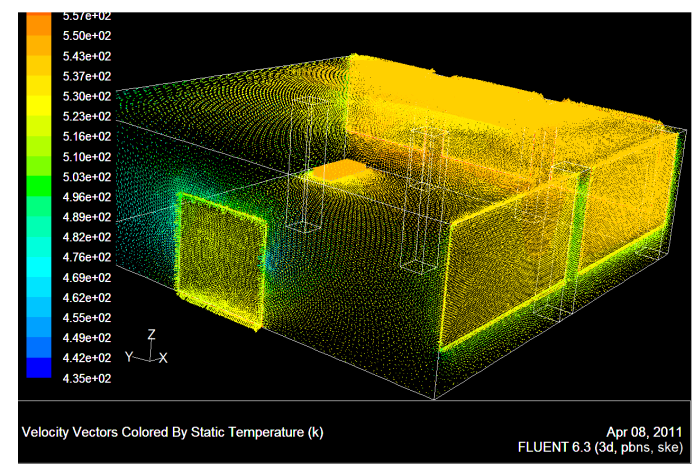

Figure 5. Complete temperature distribution in whole room

The distribution of turbulent intensity is shown in Fig. 6, that near the burning source (generator and smoke and hazards) the velocity and turbulent intensity are highest. Moreover, a the room). The areas with higher temperatures can be seen clearly, which should be considered during the evacuation of people from the room. Distribution of smoke in the room is approximately $40 \mathrm{~min}$ after starting the fire.

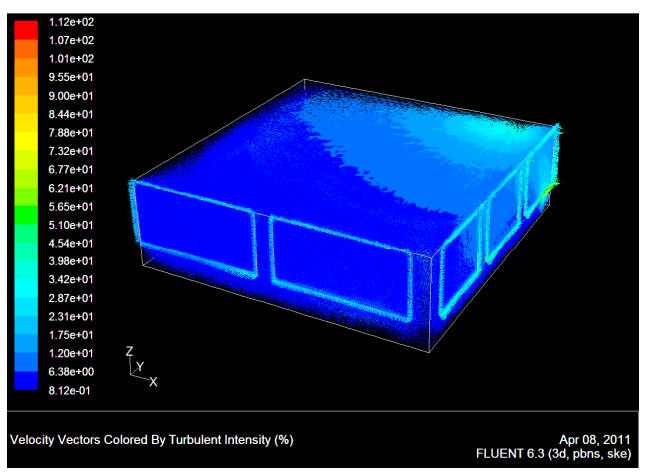

Figure 6. Distribution of turbulent intensity in the premise

similar phenomenon is observed in the joints of windows and doors. Overall, with the distance from the source turbulent intensity decreases as the outermost edge can be considered 
approximately equal to zero. The intensity is also an indicator of the degree of transport of amount of substance (mass), respectively energy. It is an obvious indicator for the direction of the processes.

All numerical results give general idea for distribution of the main parameters of the smoke (speed, temperature, pressure and turbulent intensity), which must be taken into account when designing fire protection and mechanical ventilation systems.

\section{CONCLUSION}

The work is an attempt to implement a numerical solution of the spread of smoke and hazards in the premise generated by the burning source. For this purpose was built geometric model, defined initial and boundary conditions of the problem. The mathematical model is based on fundamental transport equations - mass conservation (continuity), momentum and energy equations. The mathematical model is completed with the turbulence $k-\varepsilon$ model.

The simulation is realized with commercial CFD product. The results of numerical solution give velocity and temperature distribution of smoke in the premises. Critical areas are analyzed in the room, as well as parameter values in these areas.

\title{
NGHIÊN CÚU ẢNH HƯởNG CỦA CÁC THÔNG SỐ CƠ BẢN LÊN SỬ PHÂN BỐ KHÓI ĐỘC HẠI TRONG TÒA NHÀ BẰNG CFD
}

\author{
A. Terziev, I. Antonov ${ }^{(1)}$, Nguyen Thanh Nam ${ }^{(2)}$, Hoang Duc Lien ${ }^{(3)}$ \\ (1) Technical University-Sofia \\ (2) DCSELAB, University of Technology (HCMUT)
}

(3) Ha Noi University of Agriculture

TÓM TĂT: Trong các tòa nhà hiện đại, các tấm vật liệu polymer mới, dễ cháy thuờng được sủ dụng để dán tuờng, lót sàn, cách âm, cách nhiệt, các thiết bị và phụ kiện trang trí nội thất có thể tạo ra một lượng khói và nhiệt lớn trong thời gian ngắn khi bị cháy. Theo đó, tòa nhà có thể gây nguy hiểm đến tính mạng con người nếu xảy ra cháy. Với nhiệm vu bảo vệ con nguời khỏi các nguy hiểm, ta cần tìm câu trả lời cho các câu hỏi: khói sẽ lan tỏa thế nào trong các phòng, giải pháp nào để dập tắt ngọn lửa lan tỏa, nhũ̃ng thông số co bản nào biểu diễn sụ phân bố khói độc hại trong tòa nhà...

Trong khoa học hiện đại, các mô hình toán của ngọn lửa được sủ dụng để giải các bài toán liên quan tới quá trình cháy trong kỹ thuật chống cháy. Với muc đích đó, lời giải số được triển khai để mô phỏng quá trình cháy. Trong bài báo này, các tác giả trình bày kết quả mô phỏng số quá trình lan tỏa của khói độc hại trong phòng, cu thể với truờng vận tốc và nhiệt độ. Dựa trên kết quả lời giải số, các

\section{Trang 34}


nhân tố nguy hại được xác định giúp tối ưu hóa hệ thống chống cháy (hệ thống hút khói, thông gió...) có xét đến ảnh hưởng của các thông số vật lý trong phòng ở.

\section{REFERENCES}

[1]. Гинжбург В. Л., Какие проблемы физики и астрофизики представляются сейчас особенно важными и интересными (тридцать лет спустя, причем уже пороге XXI века), Успехи физических наук, т. 169, № 4 (1999).
[2]. Лойцянский Л. Г., Механика жидкости и газа, М., Наука (1987).

[3]. Рыжов А. М., И. Хасанов, А. Карпов, Применение полевого метода математического моделирования пожаров в помещениях. Методические рекомендации. М. ВНИиПО (2003).

[4]. Fluent \& Gambit tutorial (2006). 